\title{
REVIEW ON GREEN BUILDING RATING TOOLS WORLDWIDE: RECOMMENDATIONS FOR AUSTRALIA
}

\author{
I. M. Chethana S. ILLANKOON ${ }^{1}$, Vivian W. Y. TAM ${ }^{2,3}$, Khoa N. LE ${ }^{2}$, \\ Cuong N. N. TRAN ${ }^{2}$, Mingxue MA ${ }^{2}$ \\ ${ }^{1}$ Department of Architecture and Civil Engineering, University of Newcastle, Australia \\ ${ }^{2}$ School of Computing Engineering and Mathematics, Western Sydney University, \\ Locked Bag 1797, Penrith, NSW 2751, Australia \\ ${ }^{3}$ College of Civil Engineering, Shenzhen University, Shenzhen, China
}

Received 13 June 2018; accepted 20 May 2019

\begin{abstract}
Buildings could be led to adverse impacts on environment, such as generation of construction and demolition waste, and emission of greenhouse gases (GHG). Therefore, promotion on development of green buildings is in need. With the increasing awareness in sustainable development, various rating tools are promoted to evaluate the performance of green buildings. Nowadays, these tools function as a guideline for green building development. There are various green building rating tools developed worldwide, and various countries follow different rules, incentives and regulations. However, despite of promotion of green building rating tools, environmental issues from buildings are still significant in Australia. This research compared green building rating tools in Australia and other countries or regions around the world. This research found that rating tools in Australia lack of (1) mandatory criteria and (2) regulations and incentives. This paper recommended that governmental incentives should be promoted.
\end{abstract}

Keywords: green building, assessment tools, rating tools, Australia.

\section{Introduction}

Construction sector is regarded as one of the significant consumers of energy and generators of greenhouse gases in Australia and the worldwide (Reidy, Lederwasch, \& Ison, 2011). United States Green Building Council Research Committee (2008) mentioned that buildings in USA were responsible for $38 \% \mathrm{CO} 2$ emissions, $71 \%$ electricity consumption, $39 \%$ energy use, $12 \%$ water consumption and $40 \%$ non-industrial waste. The construction sector consumed a large quantity of energy and emits $57 \% \mathrm{CO} 2$ in the United Kingdom (European Information Service Commission, 2012). In addition, depletion of natural resources might be caused by construction activities. For instance, about $40 \%$ of the raw stones, gravels and sands, $25 \%$ of virgin wood, and $16 \%$ of water used each year were used for construction globally each year (World Watch Institute, 2015). Therefore, environmental construction, operation and demolition of buildings should be promoted. The concept of green buildings was presented in the recent years.

United States Green Building Council (2007) identified green buildings as an efficient building operation in inte- grated planning, site orientation, energy-saving technologies, on-site renewable energy-producing technologies, light-reflective materials, natural daylight and ventilation. According to Chan, Qian, and Lam (2009), green buildings could reduce negative impacts from buildings on energy consumption and environment However, DuPlessis (2007) argued that it might be difficult for the construction industry to operate in this social ecological and responsible method, because there is a lack of standard to evaluate the performance of green buildings. Therefore, green building rating tools were developed (Hoffman \& Henn, 2008) to assess performance of buildings and act as a solid yardstick in evaluation (Eichholtz, Kok, \& Quigley, 2010).

The primary role of a green building rating tool is to provide a set of criteria for contractors and designers to achieve higher environmental performance (Cole \& Larsson, 1999). Nowadays, there are varied green building rating tools serving for different purposes.

Building Research Establishment Environmental Assessment Method (BREEAM) was launched as the first

*Corresponding author. E-mail: vivianwytam@gmail.com 
rating tool (Building Research Establishment Environment Assessment Method [BREEAM], 2015). Moreover, the most widely one at present was introduced by the United States Green Building Council (USGBC), named Leadership in Energy and Environmental Design (LEED) (United States Green Building Council, 2015b). LEED is accepted and used in various countries with 1.85 million square feet of construction space certifying every day (United States Green Building Council, 2015c). Green building rating tools such as Comprehensive Assessment System for Building Environmental Efficiency (CASBEE) in Japan, Green Mark in Singapore were discussed and evaluated widely (Crawley \& Aho, 1999; Gowri, 2004; Haapio \& Viitaniemi, 2008; Reed, Wilkinson, Bilos, \& Schulte, 2011). In Australia, Green Star, Building sustainability index (BASIX) and nationwide house energy rating scheme (NatHERs) are supported and used by authority.

There are numerous researches focusing on the comparison of different rating tools. Mattoni et al. (2018) compared five green building rating tools, including CASBEE, Green Star, BREEAM, LEED and ITACA. Similarly, Doan et al. (2017) analyzed the differences and similarities among BREEAM, LEED, CASBEE and Green Star (New Zealand). Suzer (2015) compared LEED with BREEAM, SBTool, CASBEE, and Green Star. Asdrubali, Baldinelli, Bianchi, and Sambuco (2015) evaluated LEED and ITACA based two residential buildings.

Since various rating tools are introduced for green building development, a green building should be designed and constructed based on the selected green building rating tool. Furthermore, financial incentives are provided to trigger the tendency to green buildings in certain countries. However, certain countries perform well in green building development, while others are not. According to Organisation for Economic Co-operation and Development [OECD] (2015), Australia is one of the top ten greenhouse gas emitting countries. In order to alleviate this issue, Green Building Council of Australia [GBCA] (2015a) allocates $20 \%$ of weightage for greenhouse gas reduction in green buildings when evaluating green buildings, which represents that if individuals aim to obtain a Green Star certification, requirements on GHG reduction shall be fulfilled.

He, Kvan, Liu, and Li (2018) evaluated a green building with a green star certification in Australia by LEED and recommended further improvements to achieve higher scores in LEED, because there are more requirements in LEED compared to Green Star. Therefore, the same building is evaluated based on different rating tools, and different results might be derived. Therefore, reviewing various green building rating tools provides possibility to identify the varied requirements and thus enhance the performance of the green buildings.

GHG emissions from manufacturing and construction industry had increase up to $22 \%$ in 2015 . Moreover, construction industry is the second largest contributor to Australia's economy, which accounts for approximately $8 \%$ of GDP. Since 1990, there is a steady growth in the construction industry (Department of the Environment and Energy, Government of Australia, 2017c). However, increase in GHG emissions would be resulted by the steady growth of construction industry. Therefore, improvement in these green building rating tools and effective development of green buildings are in need. This paper aims to review the green building rating tools, and further provides recommendations for the green building development in Australia.

\section{Classification of green building rating tools}

There are various rating tools on green buildings, which are developed by different organizations and assess a building from environmental, social and economic perspectives. According to Baumann, Boons, and Bragd (2002), these tools could be categorised into six categories, including frameworks, analytical tools, checklists and guidelines, software and expert systems, and rating, ranking and organising tools. Figure 1 represents this classification.

From Figure 1, rating tools belong to the category of frameworks and checklists could provide basic knowledge of green buildings to their users. In addition, categories of analytical tools, software and expert systems, and rating and ranking tools are complex in nature. Moreover, Fenner and Ryce (2008) illustrated that environmental assessment tools can be classified into three types: 1) knowledge-based type which could serve as referential materials for designers; (2) performance-based type which use life-cycle impact assessment and simulation tools for calculations, such as energy consumption, lighting and indoor air quality; and (3) building rating type which is a credit rating calculator to assist designers in identifying design criteria and in documenting proposed design performance. Furthermore, categories of frameworks, checklists and guidelines on green buildings are included in environmental assessment tools of knowledge-based type. For instance, ISO 15686-5:2017: Building and construction assets - service life planning - Part 5: Life cycle costing could be classified as a knowledge-based type for the life-cycle calculation (International Standards Organisation [ISO], 2017). The performance-based type includes analytical and software and expert system rating tools. For example, software packages such as SimaPro and GaBi could be identified as a performance-based type. Finally, the category of rating, ranking and organising tools ranks the 'greenness' of buildings by stars or levels of certification. Green Star Design and As Built version 1.1 is an example as a rating tool. Furthermore, three steps are included in the rating process: 1) classification which refers to expectations of environmental changes and investigates inputs and outputs; 2) characterization which identifies the impacts from each input and output; and 3) valuation by weighting the impacts (Awadh, 2017; Fenner \& Ryce, 2008). For example, nine key criteria are listed in Green Star Design and As Built version 1.1, which identify the 


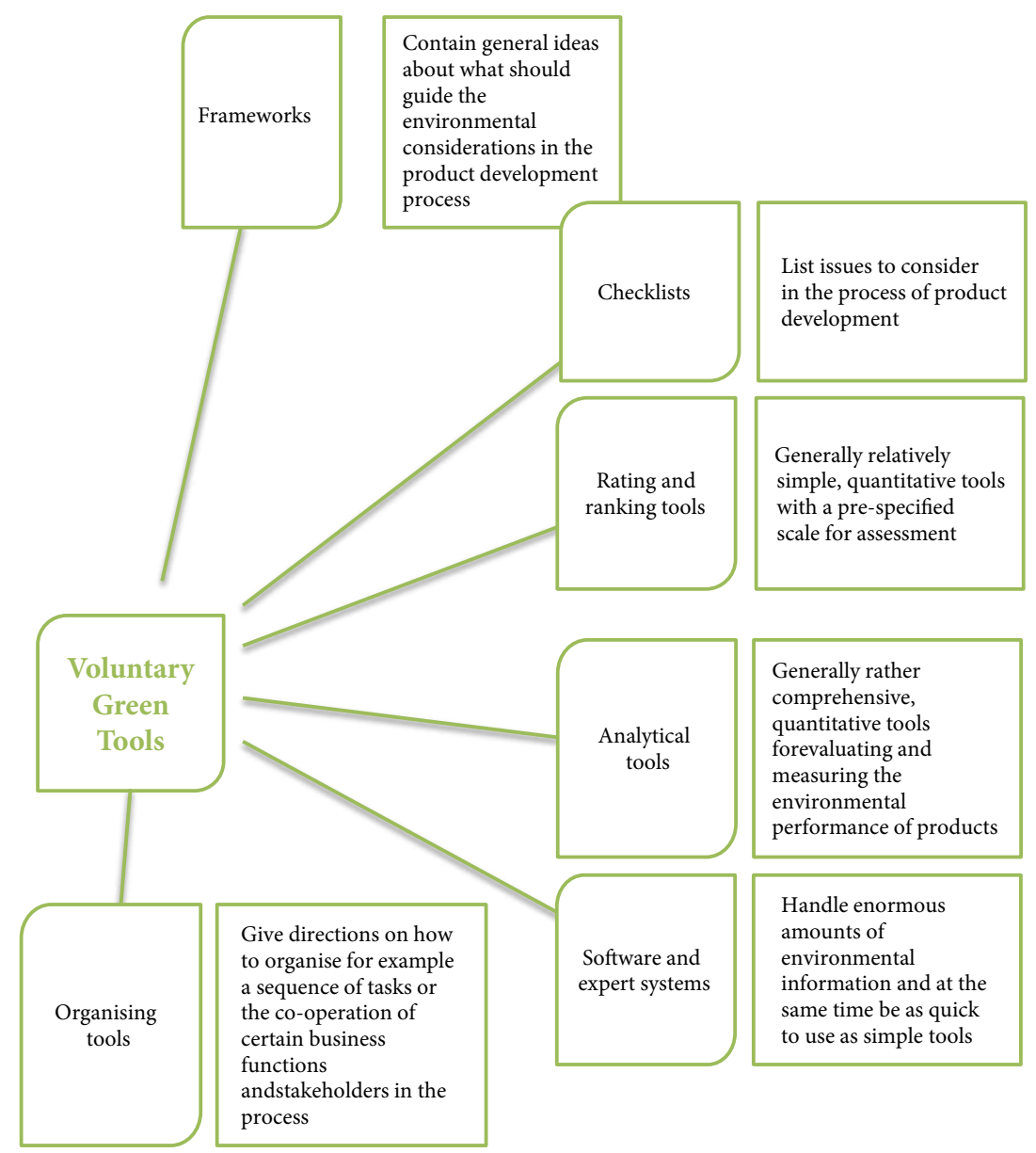

Figure 1. Classification of green building rating tools

impacts. According to Seo, Tucker, Ambrose, Mitchell, and Wang (2005), rating tools could provide indicators on quantitative performance to assist decision-making on designs. Additionally, performance levels of buildings are measured by stars in Australian context.

Categories of frameworks and checklists are usually used for rating and analysis. Furthermore, many researches had been carried out by using analytical tools, such as SimaPro (Geng et al., 2017; Ness, Urbel-Piirsalu, Anderberg, \& Olsson, 2007; Pieragostini, Mussati, \& Aguirre, 2012; Rebitzer et al., 2004; Saibuatrong, Cheroennet, \& Suwanmanee, 2017). In Australia, assessment tools give a quantitative output to support decision making among alternatives. In addition, the rating type illustrates the performance based on agreed standards. This research considers the "rating tools" that measures the performance of the green buildings based on set criteria and standards.

There are varied green building rating tools developed by different countries, the aiming to reduce adverse impacts on environment during both construction and management phases (Asdrubali et al., 2015). Usually, the contents of those tools include considerations on environmental issues, and cover different phases in the life cycle of a building. Different tools are used to assess different buildings types (residential or office building), which could be used globally. Therefore, selection of rating tools would be significantly important (Haapio \& Viitaniemi, 2008). When developing a green building rating tool, environmental quality of buildings should be taken into considerations during design and construction phases (Kohler, 1999). The performance criteria on design must be verified during the construction and commissioning (Kohler, 1999). In order to reduce the adverse impact on the environment from buildings, environmental assessments should be carried out from the initial design stage of a project (Crookes \& de Wit, 2002).

Related stakeholders might have different interests. For instance, a building owner might expect the increase of its price, whereas occupants might concern the indoor air quality, residential comfort, and safety issues (Ding, 2008). Therefore, using a single method to assess a building might not satisfy all the demands from its users. However, an ideal environmental green building rating tool would include all the requirements from related parties (Ding, 2008).

During the last decades, voluntary approaches and financial initiatives have been increasingly promoted in the construction sector to improve environmental performance (United Nations, 2004). Nowadays, there are many green building rating tools developed, launched and ac- 
cepted by the public. They are widely used to assess the performance of green buildings worldwide (Asdrubali et al., 2015; Cole, 2005; Ding, 2008; Forsberg \& Von Malmborg, 2004; Gowri, 2004; Haapio \& Viitaniemi, 2008; Reed et al., 2011). Therefore, it is necessary to identify the green building rating tools around the world.

\section{Research methodologies}

World Green Building Council is one international organisation with a network of national green building councils in more than hundred countries, who influences the green building market significantly (World Green Building Council [WGBC], 2018). With one hundred thousand buildings and almost one billion square metres of green building space registered, the strong global network of world green building council is a significant force in social and environmental changes (WGBC, 2018).

There are three different kinds of membership in WGBC: established green building councils, emerging green building councils and prospective green building councils. According to WGBC (2018), an established green building council is stable and national positioning. An emerging green building council would develop its organisation where it is operational, providing with various programmes and financial initiatives. In addition, a prospective green building council would bring together a robust group of founding members, develop a strategic plan for further development and operation as a legal entity (WGBC, 2018).

Countries with established green building councils would establish a stable and integrated functional system to evaluate and develop green buildings. However, the development of green buildings in the countries with emerging and prospective green building councils is at the initial stages. The research and analysis on these countries might fail to provide a significant reference value to further study in green building development. Therefore, countries with established green building councils are selected in this study. Furthermore, the green building rating tools used by established green building councils are listed in Table 1.

Based on Table 1, there are five major geographical areas. Each of these areas uses different rating tools based on different conditions. Therefore, a thorough investigation on each region is carried out. There are certain green building rating tools which are not widely used and are not published by an established green building council in the region. For instance, GSAS (Global Sustainability Assessment System) is a green building rating tool which is developed in Qatar. According to the WGBC (2018), Qatar has an emerging green building council, and this tool is not widely used within the region. Similarly, there are many countries with emerging green building councils. Several green building rating tools are not commonly used. Therefore, those rating tools are not included in this study. However, there are certain countries with established green building councils, but tools such as LEED are more commonly used compared with tools developed in the specific countries. For example, in UAE, 'Estidama' is used in many government projects. However, the most commonly used rating tool is LEED. Under such circumstances, the more widely used tools, such as LEED are taken into consideration in this research. Consequently, there are 27 countries with established green building councils (WGBC, 2018). These selections are discussed in detail in the following sections. After analysing the green building rating tools and relevant incentives schemes in selected countries, this study will investigate and compare the green building assessment tools and incentive schemes in Australia and other five regions.

\subsection{American region}

Based on Table 1, American region includes seven countries: Argentina, Canada, Brazil, Chile, Colombia, Peru and United States. LEED is used as a major green building rating tool in all these countries. Although that Alta Qualidade Ambiental (AQUA) process is used in Brazil, LEED is used by most users (Gomes, Silva, Lamberts, Takaoka, \& Ilha, 2008). In July 2013, the number of projects registered amounted to 769 (over 33 million $\mathrm{m}^{2}$ undergoing certification), with 109 certified in LEED (Ernst \& Young Global Limited \& Green Building Council Brazil, 2013). There are eight main criteria to evaluate green buildings in LEED, including location and transport, sustainable sites, water efficiency, energy and atmosphere, material and resources, indoor environmental quality (IEQ), regional priority and innovation. Additionally, in LEED, one credit point is allocated to the cost of green buildings, while the cost is not taken into consideration in many rating tools (Gan, Zuo, Ye, Skitmore, \& Xiong, 2015).

According to Matisoff, Noonan, and Flowers (2016), green building policies in United States require LEED certification or equivalent design and performance in construction sector. In addition, these requirements often apply to government buildings. Despite of this, five states in United States offer limited grants to cover certification costs, while ten states offer tax deductions for certifying firms (Matisoff et al., 2016). Some local governments in the United States enact various innovative policies and incentives to promote green buildings, including property tax reassessment moratoriums, green funds, parking incentives, electric bill discounts and green roof mandates (Matisoff et al., 2016).

\subsection{European region}

European countries, such as Croatia, France, Germany, Netherlands, Poland, Spain, Sweden, Turkey and United Kingdom have established green building councils (Table 1). In Europe, there are five green building rating tools being widely used, including LEED, BREEAM, DGNB in Germany, VERDE in Spain and Haute Qualité Environnementale (HQE) in France. While DGNB, VERDE and HQE are established tools, they are illustrated in German, 
Table 1. Green building rating tools in different countries

\begin{tabular}{|c|c|c|c|}
\hline Country & Region & $\begin{array}{l}\text { Name of the green } \\
\text { building council (GBC) }\end{array}$ & Green building rating tool \\
\hline Argentina & America & Argentina GBC & LEED \\
\hline Australia & Asia-Pacific & GBC Australia & Green Star \\
\hline Brazil & America & GBC Brazil & $\begin{array}{l}\text { LEED } \\
\text { Alta Qualidade Ambiental (AQUA) }\end{array}$ \\
\hline Canada & America & Canada GBC & $\begin{array}{l}\text { LEED Canada } \\
\text { Green Globes }\end{array}$ \\
\hline Chile & America & Chile GBC & LEED \\
\hline $\begin{array}{l}\text { Chinese } \\
\text { Taipei }\end{array}$ & Asia-Pacific & Taiwan GBC & $\begin{array}{l}\text { EEWS (Ecology, Energy saving, Waste and Health) } \\
\text { LEED }\end{array}$ \\
\hline Columbia & America & Columbia GBC & $\begin{array}{l}\text { Selo Ambiental Colombiano para las Edificacionis (SACE) } \\
\text { [Colombian Environmental Seal for Sustainable Building] }\end{array}$ \\
\hline Croatia & Europe & Croatia GBC & $\begin{array}{l}\text { LEED } \\
\text { BREEAM } \\
\text { DGNB (Deutsche Gesellschaft fur Nachchaltiges Bauen) }\end{array}$ \\
\hline France & Europe & France GBC & HQE (Haute Qualité Environnementale) \\
\hline Germany & Europe & $\begin{array}{l}\text { German Sustainable } \\
\text { Building Council }\end{array}$ & $\begin{array}{l}\text { DGNB } \\
\text { BREEAM Germany }\end{array}$ \\
\hline Hong Kong & Asia-Pacific & Hong Kong GBC & BEAM Plus (Building Environmental Assessment Method) \\
\hline India & Asia-Pacific & Indian GBC & $\begin{array}{l}\text { IGBC (Indian Green Building Council) Rating } \\
\text { LEED }\end{array}$ \\
\hline Japan & Asia-Pacific & $\begin{array}{l}\text { Japan Sustainable } \\
\text { Building Consortium }\end{array}$ & $\begin{array}{l}\text { CASBEE (Comprehensive Assessment System Built Environment } \\
\text { Efficiency) }\end{array}$ \\
\hline Jordan & $\begin{array}{l}\text { MENA (Middle East } \\
\text { and North Africa) }\end{array}$ & Jordan GBC & LEED \\
\hline Malaysia & Asia-Pacific & $\begin{array}{l}\text { Malaysia Green Building } \\
\text { Confederation }\end{array}$ & Green Building Index \\
\hline Netherlands & Europe & Dutch GBC & BREEAM \\
\hline New Zealand & Asia-Pacific & New Zealand GBC & Green star adapted from Green Star Australia) \\
\hline Peru & America & Peru GBC & LEED \\
\hline Poland & Europe & Polish GBC & $\begin{array}{l}\text { LEED } \\
\text { BREEAM }\end{array}$ \\
\hline Singapore & Asia-Pacific & Singapore GBC & Green Mark \\
\hline South Africa & Africa & GBC South Africa & Green Star SA (adapted from Green Star Australia) \\
\hline Spain & Europe & GBC Espana & $\begin{array}{l}\text { VERDE (Green)(From SB Tool) } \\
\text { BREEAM } \\
\text { LEED }\end{array}$ \\
\hline Sweden & Europe & Sweden GBC & $\begin{array}{l}\text { BREEAM SE (Swedish version) } \\
\text { LEED }\end{array}$ \\
\hline Turkey & Europe & Turkish GBC & $\begin{array}{l}\text { BREEAM } \\
\text { LEED } \\
\text { DGNB }\end{array}$ \\
\hline UAE & MENA & Emirates GBC & $\begin{array}{l}\text { LEED } \\
\text { BREEAM } \\
\text { ESTIDAMA (Sustainability) }\end{array}$ \\
\hline UK & Europe & UK GBC & BREEAM \\
\hline USA & America & US GBC & $\begin{array}{l}\text { LEED } \\
\text { Green Globes }\end{array}$ \\
\hline
\end{tabular}

Spanish and French. BREEAM is widely used in Europe, which includes ten criteria: management, health and wellbeing, energy, transport, water, material, waste, land use and ecology, pollution and innovation.

Apart from the rating tools on green buildings, there is a wide variety of incentives introduced in Europe to stimulate promotion of green buildings. These incentives could be categorised into three types: 1) financial and fiscal incentives; 2) economic incentives; and 3) promotion and awareness incentives. According to Brilhante and Skinner (2015), the key strategy in European Union $(\mathrm{EU})$ is to regard energy efficiency as a compulsory aspect 
which should be considered in all national building codes. Cansino, Pablo-Romero, Román, and Yñiguez (2010) illustrated that tax incentives together with promotions, such as quota obligations and price regulation are enacted in 27 members in European Union. Furthermore, an exemption on payments of electricity use when the electricity is generated from renewable energy sources is provided to few countries, such as Germany, Romania, Slovak Republic, Denmark, Sweden and Poland (Cansino et al., 2010). In addition, tax incentives in personal income are available in Belgium, France, Czech Republic and Luxembourg (Cansino et al., 2010).

According to International Labour Organisation, European Union, and International Institute of Labor Studies (2014), environmental taxes and charges are the most widely used instruments to promote green policies in the European Union. Subsidies and tax deductions have been granted for energy efficiency enhancement in various fields, including buildings.

\subsection{Asia-Pacific region}

There are numerous green building rating tools launched by respective green building councils in the Asia-Pacific region (Table 1). Australia, Taiwan, Hong Kong, India, Japan, Malaysia, New Zealand and Singapore represent Asia-Pacific region. Green Building Council in New Zealand adapted Green Star from Australia, and started to use the tool since 2007 (New Zealand Green Building Council, 2015). LEED is used as one vital rating tool in India and Taiwan. In addition, India and Taiwan are also included in the top ten countries or regions who use LEED with largest certified areas, with 13.24 million gross square metres (GSM) and 3.84 million GSM respectively (United States Green Building Council, 2015a). However, commencing from 1 July 2014, projects in India aspiring for LEED certification are required to register with IGBC. Moreover, "LEED India" projects which are already registered with IGBC before July 2014, could only continue using IGBC certification till June 2018 (Indian Green Building Council, 2014).

Energy efficiency, water efficiency, environmental performances, IEQ and other green features are considered in Green Mark rating tool. Moreover, Green Building Index also takes energy efficiency, indoor environment quality, sustainable site planning and management, material and resources, water efficiency and innovation into account. 6 criteria are listed in BEAM Plus from Hong Kong, including site aspects, material aspects, energy use, water use, indoor environment quality and innovation and additions. Sustainable architecture and design, site selection and planning, water conservation, building material and resources, indoor environment quality and innovation are considered in IGBC. CASBEE from Japan is different from other rating tools used in the Asia-Pacific region (Gan et al., 2015). Two types are included in this rating tool, such as Built Environmental Quality (Q) and Built Environmental Load (L). Targets of energy efficiency, resource efficiency, local environment and indoor environment are re-categorised under the $\mathrm{Q}$ and $\mathrm{L}$ types (Comprehensive Assessment System for Built Environment Efficiency [CASBEE], 2015).

According to Ernest \& Young (2017), Malaysian government introduced tax incentives for green technologies to develop and strengthen green technologies. Moreover, there are four types of tax incentives: 1) tax incentives for the use of energy from renewable resources; 2 ) tax incentives for energy conservation; 3 ) income tax stamp-duty incentives for GBI certified building; and 4) Feed-in Tariff system (Hashim, Zakaria, Ahzahar, Yasin, \& Aziz, 2016).

In order to maintain Singapore's image as a "city in a garden", Singapore government introduced 35 funding and incentive schemes related to energy efficiency and clean energy, green buildings and construction, water and environmental technologies, green transport and shipping, waste minimisation, environmental initiatives, and capability development (Tray, 2017).

\subsection{Middle Eastern and North African region}

Middle Eastern and North African region, Jordan and Unites Arab Emirates (UAE) are using LEED as their major green building rating tool, while Estidama is also used as the most significant green building rating tool in UAE. According to United States Green Building Council (2015a), UAE has 3.13 million GSM of certified space, and is one of top ten countries with LEED certificated areas. Separate green building regulations are applied to government buildings in Dubai and UAE, which would enforce industry wide (Salama \& Al-Saber, 2013).

\subsection{South African region}

In South Africa, Green Star from Australia is used as the major green building rating tool (Green Building Council of South Africa, n.d.; New Zealand Green Building Council, 2015). South Africa Bureau of Standards (SABS) developed a set of standards to provide a framework for energy-efficiency, and minimum requirements for best practice of green buildings (Gunnel, 2009). Sustainable building assessment tool (SBAT) is another green building rating tool used in South Africa (Gibberd, 2008). Although Green Star is designed to recognise leadership at the upper end of the green scale rather than functioning as a regulation, governments encourage the use of this tool (Gunnel, 2009). Green Building Council in South Africa supports not only the use of Green Star and also other four tools (Green Building Council of South Africa, 2018), including: 1) "EDGE" which focuses on carbon emission and reduction, water savings, and a lower cost of living in residential buildings; 2) "Energy Water Performance v1" which provides benchmarks for the energy and water consumption in existing buildings; and 3) "Net Zero" which investigates carbon, water, waste and ecology. However, all the four rating tools only focus on one or two aspects of green buildings. 


\section{Green building rating tools used in Australia}

There are tools used in the whole Australia and some tools are in certain regions. BASIX is compulsory to be used in New South Wales (NSW) for residential buildings, and NatHERS is used to evaluate thermal efficiency. Furthermore, use of NABERS and BASIX could help to obtain credit points in Green Star. These tools investigate the performance of buildings from various perspectives. For example, BASIX only focuses on residential buildings. Table 2 provides descriptions and Table 3 lists the different criteria addressed by different tools, and further introduces the uses, applications and phases of life cycle for each tool.

According to Table 3, most of these tools focus on material use, water and energy consumptions, and indoor environment quality. The assessment tools are mostly focusing on only one criterion, and rating tools usually focus on more than one criterion. However, tools such as NABERS concentrate on the performance of buildings. Tools such as Green Star investigate buildings from design perspective. There are few assessment tools observe the cost of these buildings (Table 3). All the rating tools except Green Star could be applied to separate ratings. Green Star considers all the criteria instead of focusing on sole perspective. Noise in the indoor environment quality is failed to be considered by the majority of rating tools. In addition, none of the rating tools take cost into consideration (refer Table 3).

According to GBCA (2015b), there are 663 green star certified projects in New South Wales, 13 in northern Territory, 514 in Victoria, 205 in Western Australia, 127 in South Australia, 27 in Tasmania and 367 in Queensland during October 2018. From 2004 to 2008, there were 124 projects certified in Green Star and there were 333 certified projects during last 12 months (GBCA, 2015b).

Table 2. Green building rating tools used in Australia

\begin{tabular}{|c|c|c|}
\hline Tool & Description & Reference \\
\hline AccuRate & $\begin{array}{l}\text { - Provides the benchmark for accrediting other software for use with the } \\
\text { Building Codes of Australia requirements. } \\
\text { - Allows for the physiological cooling effect of air movement, and the latest } \\
\text { developments in international simulation techniques. }\end{array}$ & $\begin{array}{l}\text { Shiel, Aynsley, Moghtaderi, and } \\
\text { Page (2017) } \\
\text { Berry and Marker (2015) } \\
\text { Seo et al. (2005) }\end{array}$ \\
\hline $\begin{array}{l}\text { BASIX } \\
\text { (Building } \\
\text { sustainability } \\
\text { index) }\end{array}$ & $\begin{array}{l}\text { - BASIX was introduced 1st July, } 2004 \text { by the New South Wales (NSW) } \\
\text { Government as a sustainable planning measure to be undertaken in Australia. } \\
\text { - Implemented under environmental planning and assessment regulations } \\
2000 \text { and environmental planning policy } 2004 \text { and applies to all residential } \\
\text { dwelling types. } \\
\text { - The BASIX is a web-based assessment tool analyzing data relating to the } \\
\text { design of the proposed dwelling and determines how this scores against water } \\
\text { and energy targets. }\end{array}$ & $\begin{array}{l}\text { NSW Department of Planing and } \\
\text { Environment }(2013,2017) \\
\text { Eroksuz and Rahman (2010) } \\
\text { Van der Sterren, Rahman, } \\
\text { Shrestha, Barker, and Ryan (2009) } \\
\text { Anderson (2006) } \\
\text { Vijayan and Kumar (2005) }\end{array}$ \\
\hline $\begin{array}{l}\text { BERS (Building } \\
\text { Energy Rating } \\
\text { Scheme) }\end{array}$ & $\begin{array}{l}\text { - Is a computer program and a powerful tool that is initially used to simulate } \\
\text { and analyze the thermal performance of Australian houses in climates ranging } \\
\text { from Alpine to tropical. } \\
\text { - Was accredited for use for energy ratings for NatHERS from 1st May } 2016 .\end{array}$ & $\begin{array}{l}\text { Nationwide House Energy Rating } \\
\text { Scheme (NatHERS) (2017) } \\
\text { Energy Inspection (2017) } \\
\text { Seo et al. (2005) }\end{array}$ \\
\hline Ecospecifier & $\begin{array}{l}\text { - Is an online database on environmentally preferable materials from glues to } \\
\text { carpets to workstation fabrics which was launched in October } 2003 \text {. } \\
\text { - Ecospecifier aims to provide guidance and hard data in a form that's easy to } \\
\text { use by designers and architects. } \\
\text { - The service is also designed to allow close integration with designers and } \\
\text { architects using the new Green Star rating system. }\end{array}$ & $\begin{array}{l}\text { EcoSpecifier Global (2017) } \\
\text { Verghese and Hes (2007) } \\
\text { Lewis and Ryan (2006) } \\
\end{array}$ \\
\hline FirstRate & $\begin{array}{l}\text { - FirstRate interactive is a tool with graphic user interface that enables designers } \\
\text { and thermal performance assessors to generate energy ratings for a home by } \\
\text { tracing over floor plans. } \\
\text { - The software integrates the AccuRate calculation engine to estimate the } \\
\text { annual heating and cooling energy and can be used to rate an existing design } \\
\text { or as an interactive tool to optimise the design beyond compliance. } \\
\text { - It is used by the majority of industry to rate the energy efficiency compliance of } \\
\text { residential dwellings to the 6-star standard under the National Construction } \\
\text { Code of Australia (NCC). } \\
\text { - Tool generates ratings based on the NatHERS } 0-10 \text { star scale for homes. }\end{array}$ & $\begin{array}{l}\text { Whaley, O'Leary, and Al-Saedi } \\
(2017) \\
\text { Victoria State Government } \\
(2017 a, 2017 b) \\
\text { Crawford, Bartak, Stephan, and } \\
\text { Jensen }(2015,2016) \\
\text { Aldawi and Alam (2016) } \\
\text { Alam and Ham (2014) } \\
\text { Mansoury and Tabatabaiefar } \\
\text { (2014) }\end{array}$ \\
\hline Green Star & $\begin{array}{l}\text { - Green Building Council of Australia (GBCA) was launched in } 2002 \text { as a } \\
\text { national not-for-profit organisation focusing on the development sustainable } \\
\text { property industry in Australia. In 2003, GBCA launched its green building } \\
\text { rating system as "Green Star". } \\
\text { - It includes four green building rating tools for Design and As Built, Interiors, } \\
\text { Communities and Performances and also it assesses the sustainability of } \\
\text { projects at all stages of life cycle. }\end{array}$ & $\begin{array}{l}\text { GBCA (2015a, 2015b) } \\
\text { Illankoon, Tam, and Le (2016a) } \\
\text { Illankoon, Tam, Le, and Shen } \\
(2016 b) \\
\text { Seo (2002) }\end{array}$ \\
\hline
\end{tabular}


End of Table 2

\begin{tabular}{|c|c|c|}
\hline Tool & Description & Reference \\
\hline $\begin{array}{l}\text { NABERS } \\
\text { (National } \\
\text { Australian Built } \\
\text { Environment } \\
\text { Rating System) }\end{array}$ & $\begin{array}{l}\text { - NABERS is a collection of separate tools, each of which calculates and rates } \\
\text { the performance of an existing building (or part of one) on a particular } \\
\text { environmental indicator at a certain point in time. } \\
\text { - Can be undertaken individually (for example, a company may decide to rate } \\
\text { its building only in energy and water), and they are not combined into an } \\
\text { overall rating. } \\
\text { - NABERS incorporates the tool formerly known as the Australian Building } \\
\text { Greenhouse Rating tool (ABGR), now known as NABERS Energy, for offices, } \\
\text { developed in } 1999 \text { by the NSW Sustainable Energy Development Authority. } \\
\text { ABGR became part of the NABERS suite of tools in } 2008 \text { and has since been } \\
\text { expanded to include water, waste, and indoor environment ratings and to } \\
\text { cover a range of building types. }\end{array}$ & $\begin{array}{l}\text { Office of Environment and } \\
\text { Heritage, Government of } \\
\text { Australia (2016) } \\
\text { Mitchell (2010) } \\
\text { Hertzsch, Heywood, Piechowski, } \\
\text { and Rowe (2011) } \\
\text { Baird (2009) } \\
\text { Bannister (2005) } \\
\text { Watson, Mitchell, and Jones } \\
\text { (2004) }\end{array}$ \\
\hline $\begin{array}{l}\text { NatHERS } \\
\text { (Nationwide } \\
\text { House Energy } \\
\text { Rating Scheme) }\end{array}$ & $\begin{array}{l}\text { - NatHERS provides Australian homes with a star rating out of ten based on an } \\
\text { estimate of a home's potential (heating and cooling) energy use. } \\
\text { - Provides a "measuring tape" for energy efficiency. } \\
\text { - Administered by the Department of the Environment and Energy on behalf of } \\
\text { the states and territories of Australia. } \\
\text { - NatHERS accredits BERS and FirstRate software for the assessment of energy } \\
\text { loads and when rating houses. }\end{array}$ & $\begin{array}{l}\text { Department of the Environment } \\
\text { and Energy, Government of } \\
\text { Australia (2017b) } \\
\text { Shiel et al. (2017) } \\
\text { Whaley et al. (2017) } \\
\text { O'Leary, Belusko, Whaley, and } \\
\text { Bruno (2016) } \\
\text { Berry and Marker (2015) } \\
\text { Graham (2003) }\end{array}$ \\
\hline
\end{tabular}

Table 3. Detailed evaluation of green building assessment and rating tools used in Australia

\begin{tabular}{|c|c|c|c|c|c|c|c|c|c|c|c|c|c|}
\hline \multirow[b]{2}{*}{ Tool } & \multirow[b]{2}{*}{ End Use } & \multirow[b]{2}{*}{ Applications } & \multirow[b]{2}{*}{ Phase $^{*}$} & \multicolumn{10}{|c|}{ Criteria } \\
\hline & & & & 预 & ָี & 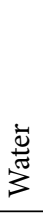 & : &  & 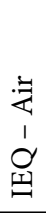 & 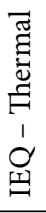 & 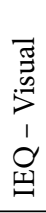 & 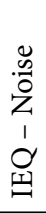 & 盛 \\
\hline AccuRate & Building & Residential building & $\mathrm{D}, \mathrm{O} \& \mathrm{M}$ & $\checkmark$ & - & - & - & - & - & $\checkmark$ & - & - & - \\
\hline BASIX & Building & Residential building & $\mathrm{P}$ and $\mathrm{D}$ & $\checkmark$ & $\checkmark$ & $\checkmark$ & $\checkmark$ & $\checkmark$ & $\checkmark$ & $\checkmark$ & $\checkmark$ & - & - \\
\hline $\begin{array}{l}\text { BERS (Building Energy } \\
\text { Rating Scheme) }\end{array}$ & Building & Residential building & $\mathrm{D}, \mathrm{O} \& \mathrm{M}$ & $\checkmark$ & - & - & - & - & - & $\checkmark$ & - & - & - \\
\hline Ecospecifier & Material & Building material & $\mathrm{D}, \mathrm{O} \& \mathrm{M}$ & $\checkmark$ & $\checkmark$ & $\checkmark$ & $\checkmark$ & $\checkmark$ & - & $\checkmark$ & - & - & - \\
\hline FirstRate & Building & Residential building & $\mathrm{D}, \mathrm{O} \& \mathrm{M}$ & $\checkmark$ & - & - & - & - & - & $\checkmark$ & - & - & - \\
\hline Green Star & Building & Buildings & $\mathrm{D}, \mathrm{O} \& \mathrm{M}$ & $\checkmark$ & $\checkmark$ & $\checkmark$ & $\checkmark$ & $\checkmark$ & $\checkmark$ & $\checkmark$ & $\checkmark$ & $\checkmark$ & - \\
\hline $\begin{array}{l}\text { NABERS (National } \\
\text { Australian Built } \\
\text { Environment Rating } \\
\text { System) }\end{array}$ & Building & $\begin{array}{l}\text { Commercial \& residential } \\
\text { buildings }\end{array}$ & $\mathrm{O} \& \mathrm{M}$ & $\checkmark$ & - & $\checkmark$ & $\checkmark$ & $\checkmark$ & $\checkmark$ & $\checkmark$ & $\checkmark$ & $\checkmark$ & - \\
\hline $\begin{array}{l}\text { NatHERS (Nationwide } \\
\text { House Energy Rating } \\
\text { Scheme) }\end{array}$ & Building & Residential building & $\mathrm{D}, \mathrm{O} \& \mathrm{M}$ & $\checkmark$ & - & - & - & - & - & $\checkmark$ & - & - & - \\
\hline
\end{tabular}

Note: ${ }^{*} \mathrm{P}$ - Planning; D - Design; O \& M - Operation and Maintenance; EoL - End-of-life.

This fact illustrates significant uptake of Green Star during the last few years and its diffusion across different states. According to GBCA (2015b), 58\% of certified buildings are office building, $22 \%$ are office interiors. Educational buildings constitute up to $11 \%$. Therefore, there might be increasing demands for the office buildings to be certified in Australia.
Tax breaks for green building programme were expected to be introduced to promote green building development across Australia. However, this program was scrapped, because of limited federal budget during 20122013 (GBCA, 2012). In Australia, tariff schemes, such as gross-feed-in-tariff scheme, a net-feed-in-tariff scheme and a buy-back scheme were enacted to encourage use of 
renewable energies (Tam, Le, Zeng, Wang, \& Illankoon, 2017). In addition, a solar credit scheme was initiated by the authority to support household owners with additional financial benefits for installing renewable energy systems (Tam et al., 2017). Moreover, governmental fundings amounting to $\$ 2.1$ million (GST exclusive) were provided for programme from 2014 to 2016 to encouage installation of renewable energy systems (solar photovoltaic panels or a solar hot water system only) in existing buildings (Department of the Environment and Energy, Government of Australia, 2017a).

\section{Findings and discussion}

This study identified various green building rating tools and incentives in five regions. In addition, green building rating tools in Australia are discussed in this study. Table 4 represents criteria of each rating tools discussed in this study.

Based on Table 4, certain aspects are considered by most of the rating tools. The key criteria such as energy and water consumption, sustainable sites, material, waste and pollution, management, and IEQ are mentioned by all the listed rating tools. However, there are differences in different rating tools. For example, the criterion on "environmental performance" covers up a wide range of aspects in Green Mark. Basically, it includes several subcategories, covering sustainable construction, sustainable products, refrigerant management and greenery provision. All the sub-categories are related to environmentally friendly materials, resources and sustainable usage of sites. Energy efficiency is significantly considered in Green Mark. Illankoon, Tam, Le, and Shen (2017) mentioned that $49.73 \%$ of credit points on energy related criteria are allowed in Green Mark. According to Kamaruzzaman, Lou, Zainon, Mohamed Zaid, and Wong (2016), the main reason to the focus on energy is the expected energy hike in the future. Therefore, the reason to the concentration on "Energy" credits by most of the green rating tools is that these credits are promoted by international organizations, representing global concerns (Doan et al., 2017).

LEED also focuses on energy criteria (refer Table 4). Based on a comparison among BREEAM, BEAM Plus and CASBEE, LEED was found to be the most stringent and relatively less flexible in its assessment criteria in terms of energy use (Lee, 2012). Mattoni et al. (2018) reported that green building rating procedures aimed at reduction of energy consumption in the recent years. Despite of the stringent criteria, actual consumption of LEED certified buildings are comparable to BREEAM and BEAM Plus (Lee, 2012). In Australia, energy use is also the focus of Green Star. Green Star allocates 24 credits out of 100 on energy. In addition, no minimum requirements are developed as conditional requirements on energy (GBCA, 2015b). However, there are conditional requirements on energy in LEED and BREEAM, but developers are required to satisfy these requirements to obtain a certification. This aspect is not in the Green Star. Therefore, in Australia, a green certification could be obtained without meeting all the basic criteria. Based on previous literatures, construction industry in Australia has contributed a large amount of GHG (Department of the Environment and Energy, Government of Australia, 2017c). One of the reasons could be a lack of minimum criteria in Green Star rating tool. Although Green Star Design and As Built rating tool allocate $20 \%$ of their credits on GHG emissions, reduction of GHG emission is not mandatory. Furthermore, a green building could still be certified without achievement of requirements on GHG reduction. Therefore, it is possible to obtain a green certification by achieving only two or three criteria out of eight. However, it is not the case in LEED and BREEAM, because they are mandatory. Therefore, there is a need to consider all the criteria holistically in Green Star when certifying Buildings.to. Development of a green rating tool which covers all the criteria is urgent.

There is a concern in sick building syndrome in Japan (Nakayama \& Morimoto, 2009). Therefore, CASBEE focuses more on IEQ criteria. 17\% of the credits are allocated to IEQ in Green Star (GBCA, 2015b). According to the survey conducted in Standing Committee on Public Works [NSW] (2001), 48\% respondents experienced eight symptoms of sick building syndrome with moderate frequently. Therefore, Australia should focus on tools such as CASBEE for further improvements.

Some criteria, such as regional priority in LEED, lifecycle approach service and life-planning in BREEAM are not adopted in Green Star. According to Illankoon, Tam, and Le (2018), it is necessary to investigate life-cycle cost and regard it as a solution to first cost premium of green buildings in Australia. Therefore, life-cycle cost approach can be included in green building assessment if this aspect is included in Australian green building rating tools such as Green Star. Costs in evaluating buildings are considered in none of the rating tools in Australia (Table 3). Based on previous literature, initial cost is one of the main concerns in green building development (Davis Langdon, 2007; Hwang \& Tan, 2012; Illankoon et al., 2016b; J.-L. Kim, Greene, \& S. Kim, 2014; Zhang, Platten, \& Shen, 2011). Therefore, ignorant of cost considerations in the green building rating tools would hinder the development of green buildings. If costs could be given attentions in the initial stages, development in green buildings might be enabled and the industry could find approaches to achieve a lower cost. Consequently, the first cost premium for green buildings would decrease as well. Software, such as $\mathrm{GaBi}$, enables the life-cycle cost calculations for green buildings. These tools should be promoted. Additionally, criteria on cost should be introduced to green certification tools. Therefore, developers could consider cost as a part of green buildings evaluation, which would provide fruitful solutions to initial cost premium issues. It will be beneficial to develop a system to reward the developers who certify green buildings with a lower initial cost. 


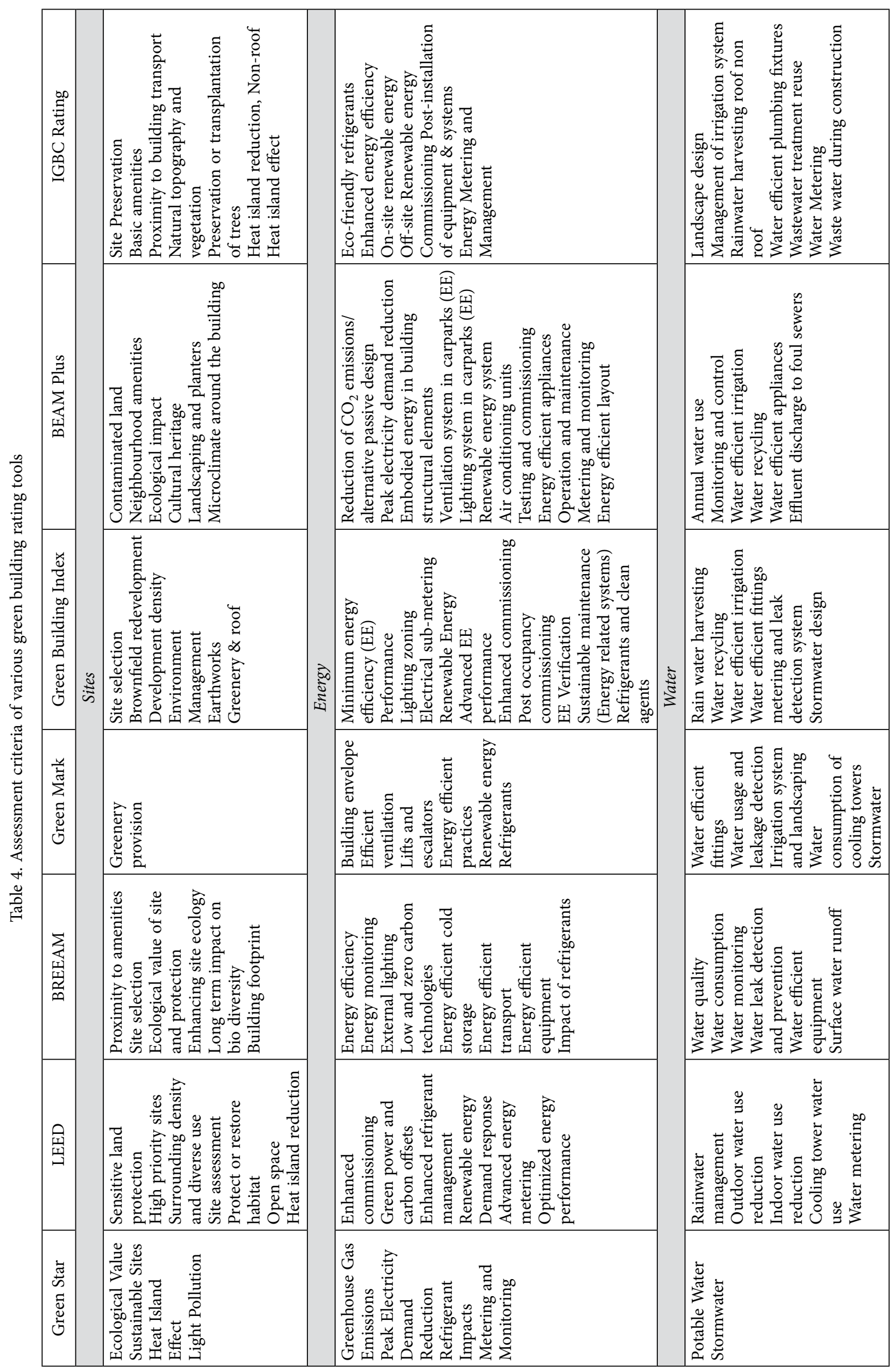




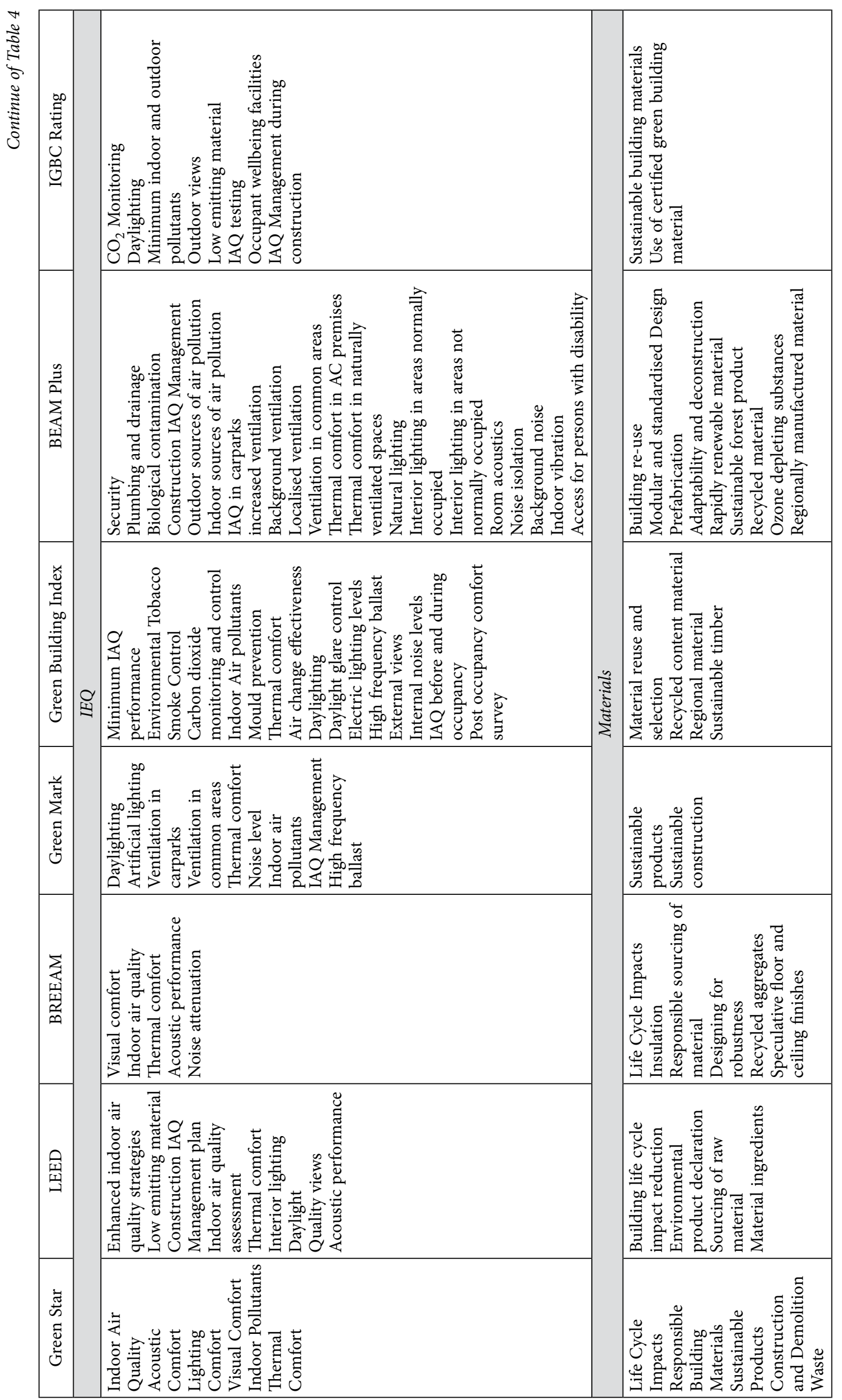




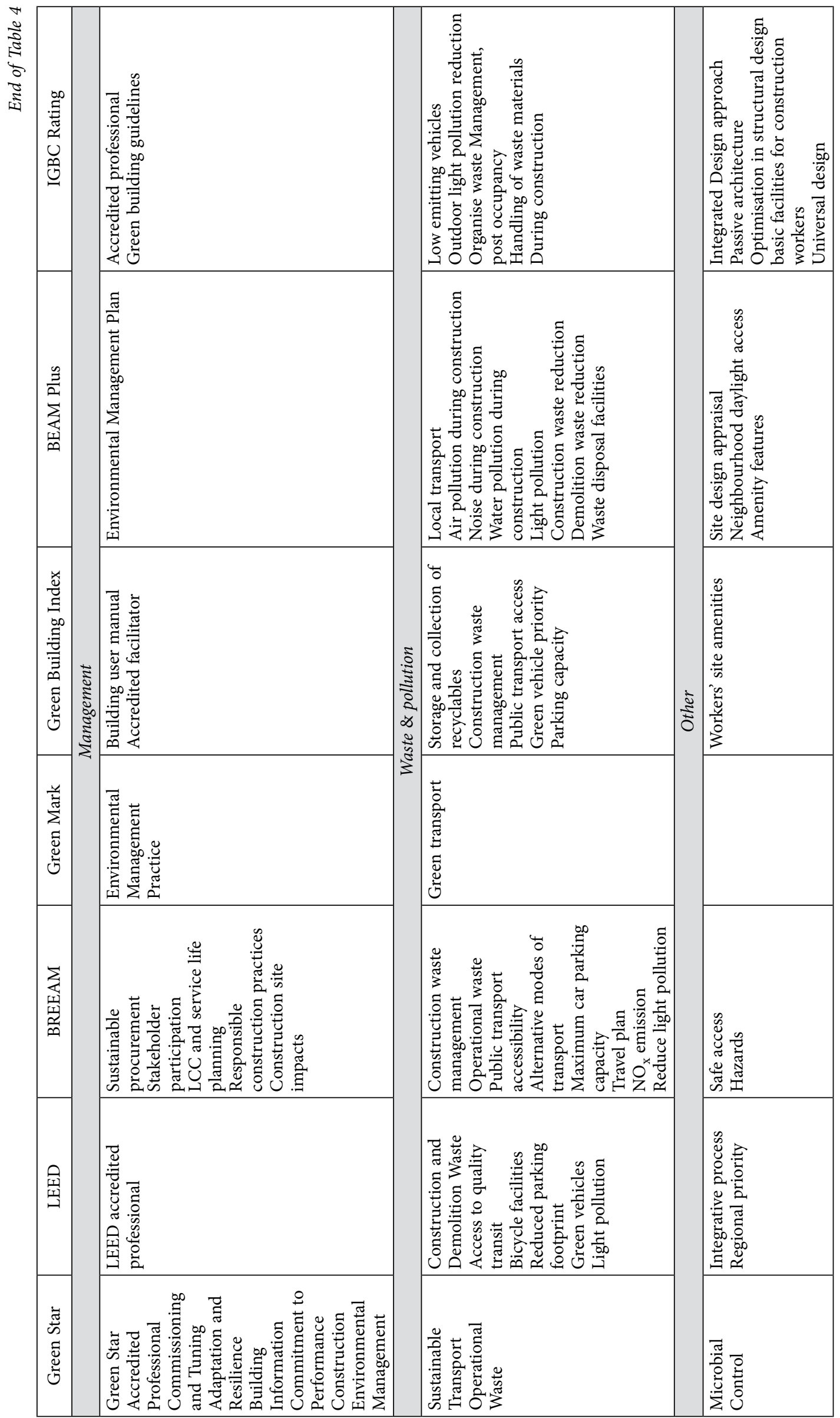


There are two major types of green building tools: (1) assessment tools; and (2) rating tools. Assessment tools are used to make a choice among different alternative options, and rating tools could provide an indication to the public. There are many green building rating tools worldwide. LEED and BREEAM are the most widely used rating tools. Criteria such as energy and water consumption, indoor environment quality, land use and waste are listed in these rating tools. Green Star from Australia also follows a similar pattern about the key criteria. Some assessment tools focus on either one or two criteria separately (Table 3). This is similar to most of the green building rating tools, except Green star.

There are different incentives provided by governments to encourage development of green buildings in different regions. Tax incentives are provided in American, European and certain parts of Asia-Pacific region. In certain European countries, there are green tax incentives in personal income. In other European countries and many countries or regions in Asia and South Africa, practices of green buildings had been developed. Provision of incentives is well practiced (Olubunmi, Xia, \& Skitmore, 2016). In addition, there are incentives on excise duties. However, there are fewer attempts on incentives in Australia. Furthermore, the focus of most available incentives is on renewable energy, but other criteria are not considered. Governmental funding is provided on the renewable energy and solar power. Moreover, incentives in European and Asian regions are widespread. Based on the previous literatures, tax incentives are considered as one of the successful factors to develop a successful green building market (Cansino et al., 2010; Hashim et al., 2016). However, effective incentive schemes are not available in Australia. Therefore, Australia should develop a tax incentive scheme. Olubunmi et al. (2016) stated that green building incentives are important in promoting green buildings. Furthermore, incentives on excise duties are also recommended. In terms of effectiveness, both external and internal incentives are important to promote green building, although it is unclear which one is more effective (Olubunmi et al., 2016). In most of the regions, many incentives are provided (Section 2). However, minimum incentives are provided by Australian government.

European and American countries have many regulations on constructing buildings. In the United States, it is mandatory to obtain a LEED or similar certification. In addition, support from governments is essential, because it would encourage developers to promote green building. However, such governmental support is not available in Australia. Although there are few requirements from State governments, there is no legal requirement to adapt green building features in building construction. According to Olubunmi et al. (2016), it is essential to enforce green building incentives and to establish proper government regulations. According to Olubunmi et al. (2016), there are limited resources to invest in green buildings, because of a lack of enforceable mechanism in developed and de- veloping countries. There are no government regulations on green buildings (Section 3). If the diffusion of green buildings across Australia could be considered, majority of the green certified projects are from NSW (Section 3). Furthermore, NABERS certification in NSW is mandatory (Table 2).

In Australia, there are various assessment tools and rating tools. However, there is a lack of integration among these tools. Different State governments have different policies and various requirements in the use of these tools. Tools, such as NatHERS and BASIX are supported by state governments. Therefore, it is necessary to implement a policy to integrate various policies and requirements of different state governments in Australia. Based on main policies, each state government could implement plans to suit the requirements. Therefore, each state could equally contribute to the green building development. Green building requirements to building codes should be implemented as a mandatory requirement. Moreover, government could mandate a minimum green certification for new developments. These requirements could be extended to private building projects.

\section{Conclusions}

This study investigated various green building rating tools and incentive schemes around the world. In addition, green building rating tools and incentives in Australia were compared with tools used in other regions of the world. There are some differences between green building rating tools in Australia and other regions or countries: 1) there is a lack of mandatory criteria in Green Star used in Australia compared with LEED and BREEAM. Certification of green buildings could be obtained without achieving all the key criteria; 2) there is a lack of regulations and incentives to promote green buildings in Australia. Five different regions had adopted tax incentives, government mandates and incentives on excise duties to support green buildings. Based on the comparison, certain developments on green buildings could be promoted in Australia. Australia needs to develop governmental policies and regulations on green buildings, provide incentives to green building development, and enrich criteria in rating tools by adding costs. This paper could provide guidance to organisations such as Green building Council of Australia on the further development of in green building tools. In addition, State governments and federal governments in Australia could realize the necessity to promote tax incentives to encourage green building development. Furthermore, governing bodies should further consider a holistic approach to integrate policies.

\section{Acknowledgements}

The authors wish to acknowledge the financial support from the Australian Research Council (ARC), Australian Government (No: DP150101015 and DP190100559). 


\section{References}

Alam, J., \& Ham, J. (2014). Towards a BIM-based energy rating system. In Proceedings of the 19th International Conference on Computer-Aided Architectural Design Research in Asia: Rethinking Comprehensive Design: Speculative Counterculture, Kyoto, Japan.

Aldawi, F., \& Alam, F. (2016). Residential building wall systems: Energy efficiency and carbon footprint. In Thermofluid Modeling for Energy Efficiency Applications (Chapter 8, pp. 169-196). https://doi.org/10.1016/B978-0-12-802397-6.00008-7

Anderson, J. M. (2006). Integrating recycled water into urban water supply solutions. Desalination, 187(1), 1-9. https://doi.org/10.1016/j.desal.2005.04.062

Asdrubali, F., Baldinelli, G., Bianchi, F., \& Sambuco, S. (2015). A comparison between environmental sustainability rating systems LEED and ITACA for residential buildings. Building and Environment, 86, 98-108.

https://doi.org/10.1016/j.buildenv.2015.01.001

Awadh, O. (2017). Sustainability and green building rating systems: LEED, BREEAM, GSAS and Estidama critical analysis. Journal of Building Engineering, 11, 25-29.

https://doi.org/10.1016/j.jobe.2017.03.010

Baird, G. (2009). Incorporating user performance criteria into building sustainability rating tools (BSRTs) for buildings in operation. Sustainability, 1(4), 1069-1086.

https://doi.org/10.3390/su1041069

Bannister, P. (2005, 15-18 August). The ABGR validation protocol for computer simulations. In Proceedings of the 9th International IBPSA Conference, Montreal, Canada.

Baumann, H., Boons, F., \& Bragd, A. (2002). Mapping the green product development field: engineering, policy and business perspectives. Journal of Cleaner Production, 10(5), 409-425. https://doi.org/10.1016/S0959-6526(02)00015-X

Berry, S., \& Marker, T. (2015). Australia's Nationwide House Energy Rating Scheme: the scientific basis for the next generation of tools. International Journal of Sustainable Building Technology and Urban Development, 6(2), 90-102. https://doi.org/10.1080/2093761X.2015.1025451

Brilhante, O., \& Skinner, J. (2015). Review of incentive mechanisms used by European municipalities to promote sustainable housing. Roterdame, Netherlands.

Building Research Establishment Environment Assessment Method (BREEAM). (2015). What is BREEAM? Retrieved from http://www.breeam.org/

Cansino, J. M., Pablo-Romero, M. d. P., Román, R., \& Yñiguez, R. (2010). Tax incentives to promote green electricity: An overview of EU-27 countries. Energy Policy, 38(10), 6000-6008. https://doi.org/10.1016/j.enpol.2010.05.055

Comprehensive Assessment System for Built Environment Efficiency (CASBEE). (2015). An overview of CASBEE. Retrieved from http://www.ibec.or.jp/CASBEE/english/overviewE.htm

Chan, E. H. W., Qian, Q. K., \& Lam, P. T. I. (2009). The market for green building in developed Asian cities -the perspectives of building designers. Energy Policy, 37(8), 3061-3070. https://doi.org/10.1016/j.enpol.2009.03.057

Cole, R. (2005). Building environmental assessment methods: redefining intentions and roles. Building Research \& Information, 33(5), 455-467. https://doi.org/10.1080/09613210500219063

Cole, R., \& Larsson, N. K. (1999). GBC'98 and GBTool: background. Building Research \& Information, 27(4-5), 221-229. https://doi.org/10.1080/096132199369345
Crawford, R. H., Bartak, E., Stephan, A., \& Jensen, C. A. (2015). Does current policy on building energy efficiency reduce a building's life cycle energy demand? In 49th International Conference of the Architectural Science Association "Living and Learning: Research for a Better Built Environment", Melbourne, Australia.

Crawford, R. H., Bartak, E. L., Stephan, A., \& Jensen, C. A. (2016). Evaluating the life cycle energy benefits of energy efficiency regulations for buildings. Renewable and Sustainable Energy Reviews, 63, 435-451.

https://doi.org/10.1016/j.rser.2016.05.061

Crawley, D., \& Aho, I. (1999). Building environmental assessment methods: applications and development trends. Building Research \& Information, 27(4-5), 300-308.

https://doi.org/10.1080/096132199369417

Crookes, D., \& de Wit, M. (2002). Environmental economic valuation and its application in environmental assessment: an evaluation of the status quo with reference to South Africa. Impact Assessment and Project Appraisal, 20(2), 127-134. https://doi.org/10.3152/147154602781766753

Davis Langdon. (2007). The cost and benefits of acheiving green buildings. Retrieved from http://www.usgbc.org/Docs/Archive/General/Docs2583.pdf

Department of the Environment and Energy, Government of Australia. (2017a). Solar towns. Retrieved from http://www. environment.gov.au/climate-change/renewable-energy/solartowns

Department of the Environment and Energy, Government of Australia. (2017b). Nationwide House Energy Rating Scheme (NatHERS). Retrieved from http://www.nathers.gov.au/

Department of the Environment and Energy, Government of Australia. (2017c). Australia's 7th National communication on climate change. Retrieved from http://unfccc.int/files/national_reports/national_communications_and_biennial_reports/ application/pdf/024851_australia-nc7-br3-1-aus_natcom_7_ br_3_final.pdf

Ding, G. K. C. (2008). Sustainable construction - The role of environmental assessment tools. Journal of Environmental Management, 86(3), 451-464.

https://doi.org/10.1016/j.jenvman.2006.12.025

Doan, D. T., Ghaffarianhoseini, A., Naismith, N., Zhang, T., Ghaffarianhoseini, A., \& Tookey, J. (2017). A critical comparison of green building rating systems. Building and Environment, 123, 243-260. https://doi.org/10.1016/j.buildenv.2017.07.007

DuPlessis, C. (2007). A strategic framework for sustainable construction in developing countries. Construction Management and Economics, 25(1), 67-76.

https://doi.org/10.1080/01446190600601313

EcoSpecifier Global. (2017). Welcome to Ecospecifier Global. Retrieved from http://www.ecospecifier.com.au/

Eichholtz, P., Kok, N., \& Quigley, J. M. (2010). The economics of green building. Review of Economics and Statistics, 95(1), 50-63. https://doi.org/10.1162/REST_a_00291

Energy Inspection. (2017). About our software. Retrieved from http://www.energyinspection.com.au/about/

Ernest \& Young. (2017). Tax incentives in Asia Pacific. Retrieved from http://www.ey.com/sg/en/services/tax/ey-tax-incentives-in-asia-pacific-malaysia

Ernst \& Young Global Limited, \& Green Building Council Brazil. (2013). Sustainable buildings in Brazil. Retrieved from http://gbcbrasil.org.br/sistema/docsMembros/ 1311141211060000005990.pdf 
Eroksuz, E., \& Rahman, A. (2010). Rainwater tanks in multi-unit buildings: A case study for three Australian cities. Resources, Conservation and Recycling, 54(12), 1449-1452.

https://doi.org/10.1016/j.resconrec.2010.06.010

European Information Service Commission. (2012). Construction sector overview in the UK. Retrieved from http://www. prismenvironment.eu/reports_prism/UK_PRISM_Environment_Report_EN.pdf

Fenner, R. A., \& Ryce, T. (2008). A comparative analysis of two building rating systems. Part 1: Evaluation. Engineering Sustainability, 161(1), 55-63.

https://doi.org/10.1680/ensu.2008.161.1.55

Forsberg, A., \& Von Malmborg, F. (2004). Tools for environmental assessment of the built environment. Building and Environment, 39(2), 223-228. https://doi.org/10.1016/j.buildenv.2003.09.004

Gan, X., Zuo, J., Ye, K., Skitmore, M., \& Xiong, B. (2015). Why sustainable construction? Why not? An owner's perspective. Habitat International, 47, 61-68.

https://doi.org/10.1016/j.habitatint.2015.01.005

Geng, S., Wang, Y., Zuo, J., Zhou, Z., Du, H., \& Mao, G. (2017). Building life cycle assessment research: A review by bibliometric analysis. Renewable and Sustainable Energy Reviews, 76, 176-184. https://doi.org/10.1016/j.rser.2017.03.068

Gibberd, J. T. (2008, 21-25 September). Sustainable building assessment tool: integrating sustainability into current design and building processes. In World Sustainable Building Conference, Melbourne, Australia.

Gomes, V., Silva, M., Lamberts, R., Takaoka, M. V., \& Ilha, M. (2008, 21-25 September). Sustainable building in Brazil. In World Sustainable Building Conference, Melbourne, Australia.

Gowri, K. (2004). Green building rating systems: An overview. ASHRAE Journal, 46(11), 56.

Graham, P. (2003). The role of environmental performance assessment in Australian building design. International e-Journal of Construction, 1-23.

Green Building Council of Australia (GBCA). (2012). Financial incentives. Retrieved from https://www.gbca.org.au/advocacy/ federal/4-financial-incentives4/

Green Building Council of Australia (GBCA). (2015a). About GBCA. Retrieved from http://www.gbca.org.au/about/

Green Building Council of Australia. (2015b). Green Star - Design and As Built version 1.1. Retrieved from https://www.gbca. org.au/green-star/green-star-design-as-built/the-rating-tool/

Green Building Council of South Africa. (2018). We certify. Retrieved from https://gbcsa.org.za/certify/

Green Building Council of South Africa. (n.d.). Green Star SA rating system. Retrieved from https://www.gbcsa.org.za/ green-star-sa-rating-system/

Gunnel, K. (2009). Green building in South Africa: Emerging trends. Retrieved from https://www.academia.edu/29569417/ Green_Building_in_South_Africa_Emerging_Trends

Haapio, A., \& Viitaniemi, P. (2008). A critical review of building environmental assessment tools. Environmental Impact Assessment Review, 28(7), 469-482. https://doi.org/10.1016/j.eiar.2008.01.002

Hashim, S. Z., Zakaria, i. b., Ahzahar, N., Yasin, M. F., \& Aziz, A. H. (2016). Implementation of green building incentives for construction key players in Malaysia. International Journal of Engineering and Technology, 8(2), 1039-1044.

He, Y., Kvan, T., Liu, M., \& Li, B. (2018). How green building rating systems affect designing green. Building and Environment, 133, 19-31. https://doi.org/10.1016/j.buildenv.2018.02.007
Hertzsch, E., Heywood, C., Piechowski, M., \& Rowe, A. (2011). Aspects of life cycle investing for sustainable refurbishments in Australia. In Sustainability in Energy and Buildings (pp. 201-210). Springer.

https://doi.org/10.1007/978-3-642-17387-5_21

Hoffman, A., \& Henn, R. (2008). Overcoming the social and psychological barriers to green building. Organization \& Environment, 21. https://doi.org/10.1177/1086026608326129

Hwang, B. G., \& Tan, J. S. (2012). Green building project management: obstacles and solutions for sustainable development. Sustainable Development, 20(5), 335-349.

https://doi.org/10.1002/sd.492

Illankoon, I. M. C. S., Tam, V. W., \& Le, K. N. (2016a). Environmental, economic, and social parameters in international green building rating tools. Journal of Professional Issues in Engineering Education and Practice, 143(2), 05016010. https://doi.org/10.1061/(ASCE)EI.1943-5541.0000313

Illankoon, I. M. C. S., Tam, V. W. Y., Le, K. N., \& Shen, L. (2016b). Cost premium and the life cycle cost of green building implementation in obtaining green star rating in Australia. In Pacific Association of Quantity Surveyors Congress (PAQS), Christchursh, New Zealand.

Illankoon, I. M. C. S., Tam, V. W., Le, K. N., \& Shen, L. (2017). Key credit criteria among international green building rating tools. Journal of Cleaner Production, 164, 209-220.

https://doi.org/10.1016/j.jclepro.2017.06.206

Illankoon, I. M. C. S., Tam, V. W. Y., \& Le, K. N. (2018). Lifecycle cost model for Green Star office buidings in Australia. In International Conference on Sustainability in Energy and Buildings (SEB18), Gold Coast, Australia. https://doi.org/10.1007/978-3-030-04293-6_19

Indian Green Building Council. (2014). LEED. Retrieved from https://igbc.in/igbc/getSearchPage.htm?pagePath=leed.jsp

International Labour Organisation, European Union, \& International Institute of Labor Studies. (2014). Green policies in the $E U$. Retrieved from https://ec.europa.eu/social/BlobServlet?d ocId $=7246 \&$ langId $=$ en

International Standards Organisation [ISO]. (2017). Building and construction assets - service life planning. Part 5: Life cycle costing.

Kamaruzzaman, S. N., Lou, E. C. W., Zainon, N., Mohamed Zaid, N. S., \& Wong, P. F. (2016). Environmental assessment schemes for non-domestic building refurbishment in the Malaysian context. Ecological Indicators, 69, 548-558. https://dx.doi.org/10.1016/j.ecolind.2016.04.031

Kim, J.-L., Greene, M., \& Kim, S. (2014). Cost comparative analysis of a new green building code for residential project development. Journal of Construction Engineering and Management, 140(5), 05014002.

https://doi.org/10.1061/(ASCE)CO.1943-7862.0000833

Kohler, N. (1999). The relevance of Green Building Challenge: an observer's perspective. Building Research and Information, 27(4-5), 309-320. https://doi.org/10.1080/096132199369426

Lee, W. L. (2012). Benchmarking energy use of building environmental assessment schemes. Energy and Buildings, 45, 326334. https://dx.doi.org/10.1016/j.enbuild.2011.11.024

Lewis, H., \& Ryan, C. (2006). Imaging sustainability. Melbourne: RMIT Publishing Press.

Mansoury, B., \& Tabatabaiefar, H. (2014). Application of sustainable design principles to increase energy efficiency of existing buildings. Building Research Journal, 61(3), 167-177. https://doi.org/10.2478/brj-2014-0013 
Matisoff, D. C., Noonan, D. S., \& Flowers, M. E. (2016). Green buildings: economics and policies. Review of Environmental Economics and Policy, 10(2), 329-346.

https://doi.org/10.1093/reep/rew009

Mattoni, B., Guattari, C., Evangelisti, L., Bisegna, F., Gori, P., \& Asdrubali, F. (2018). Critical review and methodological approach to evaluate the differences among international green building rating tools. Renewable and Sustainable Energy Reviews, 82, 950-960. https://doi.org/10.1016/j.rser.2017.09.105

Mitchell, L. M. (2010). Green Star and NABERS: learning from the Australian experience with green building rating tools. In R. Bose (Ed.), Energy effifient cities (pp. 93-130). Washington: The World Bank.

Nakayama, K., \& Morimoto, K. (2009). Risk factor for lifestyle and way of living for symptoms of sick building syndrome: epidemiological survey in Japan. Japanese Journal of Hygiene, 64(3), 689-698. https://doi.org/10.1265/jjh.64.689

Nationwide House Energy Rating Scheme (NatHERS). (2017). BERS Pro Accreditation. Retrieved from http://www.nathers. gov.au/newsletters/issue-2-june-2016/bers-pro-accreditation

Ness, B., Urbel-Piirsalu, E., Anderberg, S., \& Olsson, L. (2007). Categorising tools for sustainability assessment. Ecological Economics, 60(3), 498-508.

https://doi.org/10.1016/j.ecolecon.2006.07.023

New Zealand Green Building Council. (2015). History of Green Star. Retrieved from http://www.nzgbc.org.nz/Category? Action=View\&Category_id=293

NSW Department of Planing and Environment. (2013). Five year outcomes summary: BASIX. Retrieved from https://www. basix.nsw.gov.au/iframe/images/BASIX_Five_Year_Outcomes_Summary.pdf

NSW Department of Planing and Environment. (2017). About $B A S I X$. Retrieved from https://www.planningportal.nsw.gov. au/planning-tools/basix

O’Leary, T., Belusko, M., Whaley, D., \& Bruno, F. (2016). Comparing the energy performance of Australian houses using NatHERS modelling against measured household energy consumption for heating and cooling. Energy and Buildings, 119, 173-182. https://doi.org/10.1016/j.enbuild.2016.03.025

Office of Environment and Heritage, Government of Australia. (2016). NABERS. Retrieved from https://nabers.gov.au/public/webpages $/$ ContentStandard.aspx . module $=0$ \&template $=3$ \&include=homeIntro.htm

Olubunmi, O. A., Xia, P. B., \& Skitmore, M. (2016). Green building incentives: A review. Renewable and Sustainable Energy Reviews, 59, 1611-1621.

https://doi.org/10.1016/j.rser.2016.01.028

Organisation for Economic Co-operation and Development [OECD]. (2015). Green house gas emmissions. Retrieved from https://stats.oecd.org/Index.aspx? DataSetCode=AIR_GHG\#

Pieragostini, C., Mussati, M. C., \& Aguirre, P. (2012). On process optimization considering LCA methodology. Journal of Environmental Management, 96(1), 43-54.

https://doi.org/10.1016/j.jenvman.2011.10.014

Rebitzer, G., Ekvall, T., Frischknecht, R., Hunkeler, D., Norris, G., Rydberg, T., Schmidt, W.-P., Suh, S., Weidema, B. P., \& Pennington, D. W. (2004). Life cycle assessment: Part 1: Framework, goal and scope definition, inventory analysis, and applications. Environment International, 30(5), 701-720. https://doi.org/10.1016/j.envint.2003.11.005

Reed, R., Wilkinson, S., Bilos, A., \& Schulte, K.-W. (2011). A comparison of international sustainable building tools - An update. In The 17th Annual Pacific Rim Real Estate Society Conference, Gold Coast, Australia.
Reidy, C., Lederwasch, A., \& Ison, N. (2011). Defining zero emission buildings review and recommendations (Final report). Retrieved from http://www.asbec.asn.au/research/

Saibuatrong, W., Cheroennet, N., \& Suwanmanee, U. (2017). Life cycle assessment focusing on the waste management of conventional and bio-based garbage bags. Journal of Cleaner Production, 158, 319-334.

https://doi.org/10.1016/j.jclepro.2017.05.006

Salama, M., \& Al-Saber, T. (2013). Imposing green building regulations in Dubai. In The 29th Annual ARCOM Conference, Reading, UK.

Seo, S. (2002). International review of environmental assessment tools and databases. Retrieved from https://digitalcollections. qut.edu.au/2001/

Seo, S., Tucker, S., Ambrose, M., Mitchell, P., \& Wang, C. H. (2005). Technical evaluation of environment assessment tools (PN05.1019). Retrieved from http://www.ires.nus.edu.sg/davoslist/13.pdf

Shiel, J. J., Aynsley, R., Moghtaderi, B., \& Page, A. (2017). The importance of air movement in warmer temperatures: a novel SET $^{\star}$ house case study. Architectural Science Review, 60(3), 225-238. https://doi.org/10.1080/00038628.2017.1300763

Standing Committee on Public Works (NSW). (2001). Sick building syndrome. Retrieved from https://www.parliament.nsw. gov.au/ladocs/inquiries/2181/5207\%20Sick\%20Building\%20 Syndrome\%20Report.pdf

Suzer, O. (2015). A comparative review of environmental concern prioritization: LEED vs other major certification systems. Journal of Environmental Management, 154, 266-283. https://doi.org/10.1016/j.jenvman.2015.02.029

Tam, V. W. Y., Le, K. N., Zeng, S. X., Wang, X., \& Illankoon, I. M. C. S. (2017). Regenerative practice of using photovoltaic solar systems for residential dwellings: An empirical study in Australia. Renewable and Sustainable Energy Reviews, 75, 1-10. https://doi.org/10.1016/j.rser.2016.10.040

Tray, E. (2017). 2015 Guide to Singapore Government funding and incentives for the environment. Retrieved from http://www. greenfuture.sg/2015/02/16/2015-guide-to-singapore-government-funding-and-incentives-for-the-environment/\#8230

United Nations. (2004). United Nations Environment Programme. Sustainable consumption and production. In 8 th International High-Level Seminar on Sustainable Consumption and Production, Monterrey, Mexico.

United States Green Building Council. (2007). Making the business case for high performance green buildings. Retrieved from http://www.usgbc.org/Docs/Member_Resource_Docs/makingthebusinesscase.pdf

United States Green Building Council. (2015a). International rankings of top 10 countries for LEED green building. Retrieved from https://www.usgbc.org/articles/us-green-building-council-announces-top-10-countries-and-regions-leedgreen-building

United States Green Building Council. (2015b). LEED. Retrieved from http://www.usgbc.org/

United States Green Building Council. (2015c). LEED digital marketing brochure. Retrieved from http://leed.usgbc.org/

United States Green Building Council Research Committee. (2008). A national green building research agenda. Retrieved from http://www.usgbc.org/resources/national-green-building-research-agenda

Van der Sterren, M., Rahman, A., Shrestha, S., Barker, G., \& Ryan, G. (2009). An overview of on-site retention and detention policies for urban stormwater management in the Greater Western Sydney Region in Australia. Water International, 34(3), 362-372. https://doi.org/10.1080/02508060903115175 
Verghese, K., \& Hes, D. (2007). Qualitative and quantitative tool development to support environmentally responsible decisions. Journal of Cleaner Production, 15(8-9), 814-818. https://doi.org/10.1016/j.jclepro.2006.07.006

Victoria State Government. (2017a). About firstRate5. Retrieved from https://www.fr5.com.au/aboutus

Victoria State Government. (2017b). Sustainability Victoria. Retrieved from http://www.sustainability.vic.gov.au/servicesand-advice/business/firstrate5

Vijayan, A., \& Kumar, A. (2005). A review of tools to assess the sustainability in building construction. Environmental Progress, 24(2), 125-132. https://doi.org/10.1002/ep.10065

Watson, P., Mitchell, P., \& Jones, D. (2004). Environmental assessment for commercial buildings: Stakeholder requirements and tool characteristics (2001-006-B-01). Retrieved from https:// eprints.qut.edu.au/26859/1/26859.pdf

Whaley, D. M., O'Leary, T., \& Al-Saedi, B. (2017). Cost benefit analysis of simulated thermal energy improvements made to existing older South Australian houses. Procedia Engineering, 180, 272-281. https://doi.org/10.1016/j.proeng.2017.04.186

World Green Building Council [WGBC]. (2018). Retrieved from http://www.worldgbc.org/index.php?cID=1

World Watch Institute. (2015). Vision for a sustainable world. Retrieved from http://www.worldwatch.org/

Zhang, X., Platten, A., \& Shen, L. (2011). Green property development practice in China: Costs and barriers. Building and Environment, 46(11), 2153-2160.

https://doi.org/10.1016/j.buildenv.2011.04.031 